\begin{tabular}{|l|l|l|l|l|l|}
\hline J. Tek. Ling. & Vol. 10 & No. 1 & Hal. 09 - 18 & Jakarta, Januari 2009 & ISSN 1441-318X \\
\hline
\end{tabular}

\title{
STUDI BANDING TEKNOLOGI PENGOLAHAN LIMBAH CAIR PABRIK KELAPA SAWIT
}

\author{
Pertus Nugro Rahardjo \\ Peneliti di Pusat Teknologi Lingkungan \\ Badan Pengkajian dan Penerapan Teknologi
}

\begin{abstract}
In the last ten years Indonesia has already developed more than 15 Crude Palm Oil Factories (CPOF). Unfortunately the major of them do not have proper wastewater treatment plants (WWTP) yet. General speaking that in Indonesia the palm area has been increasing rapidly. Because of the very large palm area, almost all CPOF use a large area for the WWTP and the main processes of WWTP are anaerobic and aerobic system using large ponds as lagoons. The most environmental problems appear such as the bad quality of the effluent from WWTP and in maintaining units of the WWTP. The aim of this assessment is to compare the WWTP belong to 3 CPOF (PT. Kertajaya, PTP Nusantara IV Bah Jambi and PT. Smart Tbk) and RANUT as a research product from Palm Research Center located in Medan. Wastewater (produced by CPOF) used for Land application is also discussed and it is well known in using the wastewater to fertilize the palm plantation. A recommendation for the wastewater treatment system has been proposed. The system has eight processes including oil separation or first sedimentation, neutralization, equalization, anaerobic degradation, aerobic degradation, final sedimentation and sludge drying.
\end{abstract}

Key Words : comparison wastewater treatment plant, crude palm oil factory

\section{PENDAHULUAN}

\subsection{Latar Belakang}

Dalam 10 tahun terakhir ini Pabrik Kelapa Sawit (PKS) di Indonesia berkembang dengan sangat pesat. Sebagian besar lahan-lahan perkebunan non kelapa sawit di seluruh Indonesia berangsurangsur beralih atau diubah peruntukan menjadi lahan perkebunan kelapa sawit. Sebagai contoh ialah lahan perkebunan tebu milik Pabrik Gula di Kabupaten Pelaihari, Kalimantan Selatan, telah beralih fungsi menjadi lahan perkebunan Kelapa Sawit. dan masih banyak lahan-lahan milik kehutanan atau milik masyarakat yang telah disulap menjadi areal kebun kelapa sawit yang besar. Dengan pertumbuhan kebun

kelapa sawit, maka bermunculanlah pabrikpabrik minyak mentah kelapa sawit yang memproduksi CPO (Crude Palm Oil).

Dengan meningkatnya jumlah pabrik kelapa sawit (PKS), Indonesia telah berubah menjadi negara yang paling besar dalam produksi CPO. Itu berarti volume eksport minyak mentah kelapa sawit juga semakin besar dan jelas akan memberikan keuntungan yang sangat berarti, yaitu menambah devisa negara. Bahkan saat ini CPO telah menjadi primadona dalam komoditi eksport negara Indonesia. Namun dibalik kesuksesan tersebut, suatu 
konsekuensi lain adalah timbulnya permasalahan limbah PKS. Hampir semua pabrik kelapa sawit, bahkan yang sudah mengeksport minyak mentah kelapa sawit mempunyai kelemahan dalam hal penanganan limbahnya, baik terhadap limbah padat ataupun limbah cair. Effluent (hasil akhir yang dibuang ke alam) dari instalasi pengolahan limbah cair dari pabrikpabrik CPO yang ada di Indonesia umumnya masih belum memenuhi kriteria sesuai standar peraturan yang berlaku, misalnya kadar BOD masih di atas 100 ppm. Dengan demikian bila telah diberlakukan secara konsisten tentang standar internasional yang mensyaratkan harus adanya ecolabelling, maka pabrikpabrik CPO tersebut tidak dapat menjual atau mengekspor CPO-nya ke luar negeri. Karena itu sangat dibutuhkan penyempurnaan sistem pengolahan limbah cair untuk meningkatkan kualitas air buangan akhir yang tidak mencemarkan lingkungan sekitar pabrik CPO.

PKS PT. Kertajaya yang berlokasi di Kabupaten Pandeglang telah beroperasi lebih dari 20 tahun. Dalam memproduksi minyak mentah kelapa sawit, pabrik ini telah mengalami beberapa kali rehabilitasi dan pengembangan kearah kesempurnaan, sehingga semakin lama efisiensi proses produksinya mengalami peningkatan. Namun perbaikan unit-unit proses dalam pabrik tersebut tetap saja belum optimal dan jumlah kandungan minyak yang terdapat dalam limbah cairnya masih juga menunjukkan angka yang tinggi1). Sementara itu dalam unit fatpit (kolam limbah minyak) upaya pengutipan kembali minyak yang terkandung dalam limbah cair juga masih jauh dari sempurna, sehingga kualitas limbah cair yang masuk ke dalam unit pengolahan limbah cair masih mempunyai beban BOD rata-rata lebih dari 20.000 ppm. Sistem proses dalam IPAL PKS PT. Kertajaya juga tergolong sangat tidak memenuhi syarat. Berdasarkan informasi dari pemerintah daerah kualitas hasil pengolahan limbah cairnya masih melampaui nilai ambang batas yang telah diatur dalam peraturan pemerintah. Demikian pula halnya dengan PKS dari PTP. Nusantara Bah Jambi yang juga belum optimal dalam hal pengelolaan limbah cair PKSnya $^{2}$. Dilain pihak lembaga-lembaga riset yang mengembangkan teknologi proses pengolahan limbah cair PKS juga belum terlalu banyak. Dengan kemampuan dana yang sangat terbatas lembagalembaga tersebut telah berupaya sebaik mungkin untuk dapat menghasilkan sistem proses dan perangkatnya dalam mengolah limbah cair PKS. Salah satu hasil nyata yang telah ditunjukkan oleh PPKS (Pusat Penelitian Kelapa Sawit) di Medan adalah teknologi RANUT yang merupakan unit pengolah limbah cair PKS dengan sistem yang efisien. Dengan adanya berbagai teknologi pengolahan limbah cair PKS tersebut, maka dibutuhkan kajian untuk membandingkan beberapa sistem pengelolaan limbah cair PKS yang selama ini ada dan telah diterapkan secara umum.

\subsection{Tujuan}

Tujuan melakukan studi banding teknologi pengolahan limbah cair PKS ini adalah untuk melihat kekurangankekurangan dan atau kelebihan-kelebihan yang ada di dua PKS. Selanjutnya hasil pembandingan ini akan menjadi bahan masukan bagi dua PKS tersebut.

\subsection{Ruang Lingkup}

Yang dijadikan obyek pengkajian dalam studi perbandingan adalah PKS PTP. Nusantara VIII PT. Kertajaya, PKS PTP. Nusantara IV Bah Jambi, PKS Riau PT. Smart Tbk. dan suatu sistem pengolahan limbah cair PKS hasil riset dari PPKS (Pusat Penelitian Kelapa Sawit).

\subsection{Metodologi}

Dalam membandingkan jenis teknologi proses pengolahan limbah cair PKS dibutuhkan beberapa tahapan, yaitu studi literatur, survey lapangan dan analisa serta evaluasi dalam perbandingan berdasarkan hasil survey lapangan. Untuk dapat 
menguraikan permasalahan dalam pengelolaan limbah cair suatu PKS, paling tidak dibutuhkan juga literatur-literatur tentang proses pengolahan dalam memproduksi minyak mentah kelapa sawit. Pustaka tentang beberapa sistem pengolahan limbah cair PKS yang sudah ada di Indonesia juga tetap dibutuhkan sebagai bahan perbandingan. Setelah diperoleh bahan yang cukup tentang segala proses pengolahan limbah cair PKS, baru dilakukan survey lapangan, yaitu melihat langsung bagaimana kondisi terkini IPAL PKS di masing-masing PKS yang akan diperbandingkan. Dari data yang diperoleh pada saat survey dan hasil analisa laboratorium hasil pengolahan limbah cair dari air contoh yang diambil di beberapa titik lokasi IPAL, kemudian dilakukan analisa secara kuantitatif dan kualitatif.

\section{PERBANDINGAN TEKNOLOGI PENGOLAHAN LIMBAH CAIR PKS}

\subsection{PTP. Nusantara VIII}

PTP. Nusantara VIII mempunyai pabrik kelapa sawit (PKS) yang disebut PKS. Kertajaya dan terletak di Kabupaten Lebak dan Pandeglang, Propinsi Banten. Kapasitas PKS. Kertajaya adalah sebesar 30 ton TBS per jam. Karena pengoperasian pabrik hanya berjalan 2 (dua) shift per hari, maka lama waktu operasi hanyalah 16 jam per hari. Jumlah limbah cair yang dihasilkan dalam satu hari adalah sekitar $300 \mathrm{~m}^{3}$.

\section{Proses Pengolahan Limbah Cair}

1. Limbah cair yang berasal dari Unit Sludge Separator dan Unit Pencucian (klarifikasi) dialirkan ke bak Fatpit. Limbah dalam Fatpit dipanaskan dengan menggunakan steam pada temperatur $85-95^{\circ} \mathrm{C}$. Pada temperatur tersebut minyak yang masih terkandung dalam air limbah akan mudah lepas. Minyak yang dapat diambil kembali (oil recovery) dari unit ini sebesar 0,8-1,2 $\%$. Waktu tinggal (Detention Time) $\mathrm{T}_{d}=$ 16 Jam. Dimensi unit ini adalah luas 6 x $40 \mathrm{~m}^{2}$ dan kedalaman $0,8 \mathrm{~m}$ (bila dihitung dari data waktu tinggal dan debit Q sebesar 18 ton/jam). BOD dari Fatpit ini adalah $30.000-40.000$ ppm dengan pH sekitar $4-5$.

2. Proses kedua adalah anaerobik yang diakomodasikan dalam bak berjumlah 4 buah dan dioperasikan secara berurutan. Limbah cair yang masuk ke dalam bak anerobik ini adalah limbah cair dari fatpit dan limbah cair Unit Kondensat Sterilisasi, Pencucian Hydro Cyclone dan dari Unit Demineralisasi. Waktu tinggal (total) $\mathrm{T}_{\mathrm{d}}=40$ hari (bila dihitung dari pembagian volume dengan debit diperoleh $\mathrm{Td}=38,4$ hari), dengan dimensi untuk setiap baknya adalah luas $20 \times 40 \mathrm{~m}^{2}$ dan kedalaman sekitar 3 - 4 meter. Kualitas BOD dari air limbah yang keluar dari proses anaerobik ini sekitar 3000 ppm dengan $\mathrm{pH}$ antara $5-6$. Bak anaerobik ini merupakan bak terbuka dan dikatakan berproses anaerobik karena kedalaman baknya yang sampai 4 meter.

3. Proses terakhir adalah aerobik yang diakomodasikan dalam 4 buah bak (pond). Luas total unit aerobik ini adalah $75 \times 40 \mathrm{~m}^{2}$ dengan kedalaman 1,5 meter. Waktu Tinggal $T_{d}=60$ hari (bila dihitung dari pembagian volume dengan debit diperoleh Td 62,5 hari). Proses aerobik dianggap dapat terlaksana hanya dengan kontak udara di permukaan kolam, tanpa aerator mekanik atau blower. BOD limbah yang keluar dari unit ini sekitar 200 - 230 ppm dengan $\mathrm{pH}$ sekitar 7 .

4. Dalam pengoperasiannya direncanakan sebagian dari air limbah yang keluar dari unit anaerobik dipergunakan untuk menyiram tanaman. 


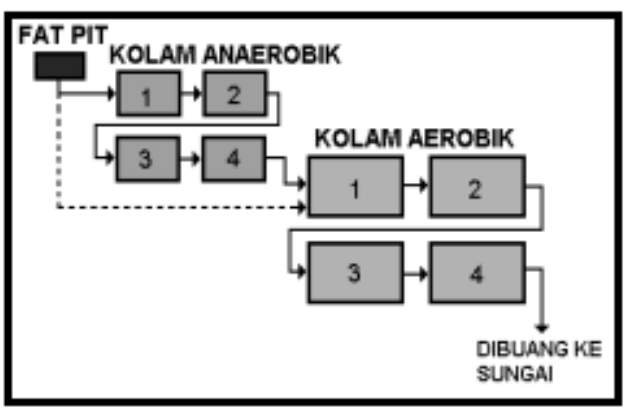

Gambar 1 : Diagram Alir Proses Pengolahan Limbah di PKS PT. Kertajaya ${ }^{11}$.

Secara umum pengolahan limbah cair dari PKS. Kertajaya dapat dikatakan sangat tidak memenuhi syarat sebagai unit/ instalasi pengolahan air limbah (IPAL). Pengoperasian dan pemeliharaan pada unit Fatpit tidak dijalankan secara benar, sehingga endapan lumpur yang begitu banyak mengisi seluruh sub unit terakhir dari bagian fatpit tersebut. Kolam-kolam anaerobik mau pun aerobik tidak dipelihara dengan baik, sehingga endapan lumpur yang semakin lama semakin banyak menjadikan seluruh pengolahan pada kolamkolam tersebut berjalan secara anerobik.
Tetapi berdasarkan hasil analisa kualitas limbah cair yang dilakukan oleh Pusat Penelitian Lingkungan Hidup, Lembaga Penelitian IPB, Bogor, pada tanggal 2 Maret 2001 menunjukkan hasil yang cukup mengejutkan, yaitu unit-unit pengolahan yang dimiliki oleh PKS. Kertajaya ternyata masih dapat menurunkan beban pencemaran hingga memenuhi baku mutu lingkungan yang telah ditetapkan oleh Pemerintah Indonesia. Kenyataan ini harus dikaji ulang secara lebih teliti lagi.

\subsection{Pengolahan Limbah Cair PTP. Nusantara IV Bah Jambi}

P.T. Perkebunan Nusantara IV Bah Jambi terletak di Propinsi Sumatera Utara dan tersebar di beberapa Daerah Tingkat II, yaitu Kabupaten Simalungun, Deliserdang, Asahan, Labuan Batu, Langkat, Tobasa, Tapanuli Selatan dan Kota Medan. PTPN. IV Bah Jambi mempunyai areal yang sangat luas dan mengelola komoditi kelapa sawit, kakao dan teh. Luas Perkebunan Kelapa Sawit sebesar $120.780 \mathrm{Ha}$ dan Pabrik Kelapa Sawit yang beroperasi untuk

Tabel 3 : Hasil Analisa Laboratorium Limbah Cair PKS. Kertajaya

\begin{tabular}{|r|l|c|c|c|}
\hline N0 & \multicolumn{1}{|c|}{ PARAMETER } & SATUAN & $\begin{array}{c}\text { Outlet } \\
\text { Anaerob }\end{array}$ & $\begin{array}{c}\text { Outlet } \\
\text { Aerob }\end{array}$ \\
\hline 1 & Padatan Terlarut Total & $\mathrm{Mg} / \mathrm{l}$ & 1.000 & 350 \\
\hline 2 & $\begin{array}{l}\text { Padatan Tersuspensi } \\
\text { Total }\end{array}$ & $\mathrm{Mg} / \mathrm{l}$ & 1.790 & 99 \\
\hline 3 & $\mathrm{PH}$ & - & 4 & 5 \\
\hline 4 & $\mathrm{BOD}$ & $\mathrm{Mg} / \mathrm{l}$ & 829 & 72,64 \\
\hline 5 & $\mathrm{COD}$ & $\mathrm{Mg} / \mathrm{l}$ & 1465,32 & 198,02 \\
\hline 6 & Amoniak Bebas & $\mathrm{Mg} / \mathrm{l}$ & 1,831 & 0,458 \\
\hline
\end{tabular}

Sumber : PPLH, IPB, Bogor (2 Maret 2004).

Proses pengolahan secara aerobik tidak dilakukan dengan penghembusan udara dari dasar kolam atau pun dengan pengadukan di permukaan kolam. Jadi jelas bahwa pengolahan secara aerobik sudah tidak berjalan optimal, jadi hanya pada sebagian kecil permukaan kolam aerobik saja yang masih berjalan dengan proses aerobik. mengolah seluruh panen dari perkebunan kelapa sawit berjumlah 16 buah. Sesuai dengan undang-undang dan peraturan yang berlaku, PTP Nusantara IV Bah Jambi telah melaksanakan pengendalian limbah cair dari pabrik kelapa sawit, yaitu dengan memiliki IPAL (Instalasi Pengolahan Air Limbah) untuk setiap pabrik kelapa sawit ${ }^{2}$. 
IPAL yang dimiliki oleh ke 16 pabrik kelapa sawit umumnya adalah dengan sistem yang konvensional, yaitu yang terdiri dari beberapa unit kolam anaerobik, fakultatif dan aerobik. Masing-masing IPAL dari setiap pabrik kelapa sawit mempunyai kolamkolam yang memiliki kedalaman, luas dan volume yang berbeda-beda. Dengan demikian waktu tinggal atau WPH (Waktu Penahanan Hidrolysis)-nya juga berbedabeda. Luas kolam yang terkecil adalah $6.800 \mathrm{~m}^{2}$, sedangkan yang terbesar adalah $42.500 \mathrm{~m}^{2}$. Sementara itu Volume kolam bervariasi dari $19.200 \mathrm{~m}^{3}$ sampai 125.500 $\mathrm{m}^{3}$ dan Waktu Tinggal yang terkecil 36 hari dan yang terbesar ialah 192 hari. Untuk mengevaluasi seluruh IPAL yang ada dalam PTP. Perkebunan IV menjadi sangat sulit. Berdasarkan laporan dari pengelola IPAL di Bah Jambi, seluruh IPAL yang dimilikinya mampu beroperasi dan dapat menurunkan kadar BOD hingga 250 ppm (Standar kualitas limbah cair berdasarkan Keputusan Menteri No. Kep-51/Men-LH-10/1995). Berdasarkan ketentuan yang berlaku sekarang, BOD yang boleh dilepas ke lingkungan adalah 100 ppm. Dengan demikian semua IPAL harus diperbaiki atau dimodifikasi , sehingga mampu menurunkan BOD hingga 100 ppm.

Perlu diketahui pula, bahwa konstruksi kolam-kolam tersebut tidak memenuhi syarat yang berlaku, karena tidak menggunakan dasar yang kedap air, tetapi hanya tanah biasa. Jadi kolam-kolam tersebut hanya merupakan kolam galian biasa. Berdasarkan informasi yang masih sangat terbatas ini, maka dapat disimpulkan bahwa sistem IPAL di area PTP. Nusantara IV Bah Jambi perlu di evaluasi kembali, diperlukan modifikasi untuk menyesuaikan dengan peraturan yang baru.

\subsection{Pengolahan Limbah PKS Riau PT. SMART Tbk}

Kapasitas PKS PT. Smart Tbk di Riau ini adalah sebesar 60 ton TBS/jam. Jumlah limbah cair yang dihasilkan sekitar $650 \mathrm{~m}^{3} /$ hari, namun kapasitas unit pengolahan limbah cairnya sebesar $885 \mathrm{~m}^{3} /$ hari. Sebagian limbah cairnya dimanfaatkan untuk land application. Seperti juga pada umumnya PKS yang lain, unit pengolahan limbah cair utama yang dimaksudkan untuk mendegradasi bahan pencemar diakomodasikan melalui dua proses, yaitu anaerobik dan aerobik. Setelah proses netralisasi dan kemudian pendinginan, baru dialirkan masuk ke dalam kolam-kolam anaerobik yang berjumlah 6 unit dan berukuran sangat luas. Dari pengolahan anaerobik, air limbah olahan masuk ke dalam kolam-kolam aerobik. Sayangnya pada kolam-kolam aerobik ini tidak semua diaerasi secara mekanik. Hanya dua kolam aerobik pertama dari 6 buah kolam yang mempunyai motor pengaduk di permukaan kolam. Berdasarkan informasi dari kepala divisi limbahnya, unit aerasi ini juga tidak sepenuhnya berjalan secara terus-menerus, tetapi sering kali bermasalah dan tidak dapat beroperasi lagi. Dengan kondisi seperti ini maka kolam-kolam aerobik ini sebenarnya sama saja dengan kolam anaerobik. Unit terakhir dari sistem pengolahan limbah cair PT.Smart Tbk. adalah sedimentasi. Waktu tinggal total membutuhkan 160 hari dan efisiensi pengolahan secara total mencapai $99 \%$. Kualitas efluen unit pengolahan limbah cair untuk beberapa parameter, yaitu TS < $5000 \mathrm{ppm}, \mathrm{pH}$ antara 7,9 sampai dengan 8,5 , BOD sekitar 50 sampai $60 \mathrm{ppm}$ dan COD berkisar antara 500 sampai 600 ppm. Menurut pihak manajemen PT. Smart Tbk, dengan sistem pengolahan limbah cair seperti itu biaya operasional untuk unit IPAL (Instalasi Pengolahan Air Limbah) dapat ditekan lebih rendah.

\subsection{Pengolahan Limbah Cair dengan RANUT}

PPKS (Pusat Penelitian Kelapa Sawit) di Medan telah mengembangkan suatu teknologi pengolahan limbah cair dari proses produksi minyak mentah sawit. Latar belakang pengembangan teknologi ini 
adalah karena melihat sistem teknologi pengolahan limbah cair yang ada umumnya masih konvensional, dimana masih menggunakan kolam anaerobik, fakultatif dan aerobik. Sistem konvensional ini membutuhkan lahan yang sangat luas, serta membuang gas metana yang dihasilkan dan terlalu banyak akumulasi lumpur, sehingga memerlukan biaya tinggi untuk pembuangannya. PPKS telah bekerja sama dengan UTEC GmBH, Jerman untuk melakukan penelitian dalam menerapkan sistem RANUT (Reaktor Anaerobik Unggun Tetap) untuk mengolah limbah cair dari pabrik kelapa sawit yang banyak terdapat di Indonesia.

Dalam sistem pengolahan limbah cair tersebut, RANUT merupakan intinya. Sistem pengolahan ini dibuat dalam skala pilot plant. Reaktor berdiameter $40 \mathrm{~cm}$ dan tinggi $250 \mathrm{~cm}$, serta berjumlah dua buah. Didalamnya terdapat unggun tetap yang menggunakan media pendukung berupa potongan pipa-pipa PVC (dengan dinding bergelombang). Dalam proses pengolahannya, limbah cair dari kolam Fatpit mengalir ke dalam RANUT pertama dari bawah ke atas. Sebagian effluentnya diresirkulasikan untuk mengencerkan limbah cair yang baru masuk dan menaikkan $\mathrm{pH}$ nya, sedangkan sebagian besar effluentnya mengalir ke dalam RANUT kedua yang mempunyai arah aliran dari atas ke bawah. Effluent dari RANUT kedua ini, yang sudah dapat memenuhi ketentuan BML (baku mutu lingkungan) dibuang ke badan air penerima. Gas yang dihasilkan dari proses anaerobik ini ditampung dan diukur dengan menggunakan Gas Meter.

Hasil dari percobaan dalam pengoperasian RANUT menunjukkan bahwa kecepatan pengurangan COD (Chemical Oxygen Demand) sebagai fungsi dari laju pembebanan tidak memperlihatkan perbedaan berarti antara reaktor pertama dan kedua. Pada laju pembebanan sebesar $8 \mathrm{~kg} \mathrm{O}_{2} / \mathrm{m}^{3} /$ hari dapat menghasilkan laju degradasi sebesar $90 \%$. Laju pembebanan maksimum yang digunakan adalah $10,5 \mathrm{~kg}$ $\mathrm{O}_{2} / \mathrm{m}^{3} /$ hari. Waktu penahanan hidrolisis minimum adalah 1,3 hari, sedangkan maksimum 20 hari. Produksi gas spesifik sekitar $0,55 \mathrm{~m}^{3} / \mathrm{kg}$ COD terlarut. Kandungan gas metana bervariasi antara $62 \%$ sampai $67 \%$, dengan rata-rata sebesar $64 \%^{3)}$. Kebutuhan energi dalam mengoperasikan sistem ini hanya untuk memompa limbah cair dan resirkulasi effluent. Energi yang dibutuhkan sebesar 4 Wh per $\mathrm{m}^{3}$ limbah cair yang diolah per meter tinggi reaktor. Pada skala penuh dibutuhkan listrik sekitar $36 \mathrm{Wh}$ per $\mathrm{m}^{3}$ limbah cair yang diolah. Perbandingan antara energi listrik yang dibutuhkan dengan potensi energi listrik yang dihasilkan menunjukkan bahwa kebutuhan listrik sebesar $0,035 \mathrm{KWh} / \mathrm{m}^{3}$ limbah cair sangat kecil dibandingkan dengan potensi produksi sebesar $16-32$ $\mathrm{KWh} / \mathrm{H} / \mathrm{m}^{3}$.

Satu kelemahan dalam sistem RANUT ini adalah adanya kemungkinan terjadinya penyumbatan dalam reaktor karena terbentuknya biofilm yang berlebihan dan timbulnya endapan disekitarnya. Jika limbah cair mengandung terlalu banyak padatan tersuspensi (lebih dari range $1000-5000$ $\mathrm{mg} / \mathrm{l})$, maka pertumbuhan bakteri akan terlalu cepat dan hal tersebut dapat menyebabkan terjadinya penyumbatan dalam reaktor. Resiko terjadinya penyumbatan pada reaktor kedua (aliran dari atas ke bawah) adalah lebih besar lagi. dengan demikian keterbatasan dari penggunaan sistem RANUT ini adalah COD terlarut berkisar antara 6 dan $8 \mathrm{~kg} / \mathrm{m}^{3} /$ hari dengan jumlah padatan tersuspensi tidak lebih dari $5000 \mathrm{mg} / \mathrm{l}$.

\subsection{Land Application}

Land Application atau aplikasi lahan adalah pemanfaatan limbah cair dari industri kelapa sawit untuk digunakan sebagai bahan penyubur atau pemupukan tanaman kelapa sawit dalam areal perkebunan kelapa sawit itu sendiri. Dasar dari land application ini adalah bahwa dalam limbah cair pabrik 
kelapa sawit mengandung unsur-unsur yang dapat menyuburkan tanah. Unsur-unsur tersebut adalah Nitrogen, Phosphor dan Kalium. Jumlah Nitrogen dan Kalium dalam limbah cair pabrik kelapa sawit sangat besar, sehingga dapat bertindak sebagai nutrisi untuk tumbuh-tumbuhan.

Limbah cair pabrik kelapa sawit yang dapat digunakan untuk land application adalah limbah cair yang sudah diolah sedemikian rupa sehingga kadar BOD-nya berkisar antara $3.500 \mathrm{mg} / \mathrm{l}$ sampai $5.000 \mathrm{mg} /$ I. Dengan komposisi yang cukup kaya akan unsur hara ( $N$, $\mathrm{P}$ dan $\mathrm{K})$, maka limbah cair tersebut mempunyai potensi yang baik untuk menggantikan peran pupuk anorganik. Dengan pemanfaatan limbah cair tersebut untuk keperluan pemupukan, maka dengan sendirinya jumlah limbah cair yang masih harus diolah juga akan berkurang. Jadi land application akan mengurangi beban biaya dan waktu untuk pengolahan limbah. Pemanfaatan limbah cair dengan land application dapat menurunkan biaya pengolahan limbah sekitar $50 \%-60 \%$.

Berdasarkan penelitian yang telah dilakukan oleh para ahli perkebunan sawit di Indonesia, limbah cair pabrik kelapa sawit yang sudah diolah dengan proses anaerobik (BOD maksimal 5.000 mg/l) merupakan sumber air dan nutrisi bagi tanaman. Disamping itu limbah cair tersebut juga mampu memperbaiki sifat dan struktur fisik tanah, meningkatkan infiltrasi tanah, meningkatkan kelembaban tanah, menambah kandungan senyawa organik, menaikkan $\mathrm{pH}$ tanah, meningkatkan aktivitas mikro flora dan fauna tanah dan dapat meningkatkan produksi tanaman kelapa sawit.

Sudah banyak PKS yang melakukan Land Application, misalnya 4 PKS di PTPN IV Bah Jambi, yaitu PKS Pulu Raja, Adolina, Sosa dan Bah Jambi yang keempatnya mempunyai luas land application sebesar sekitar $600 \mathrm{Ha}$. Memang belum ada standar yang baku dalam pemanfaatan limbah cair PKS melalui Land Application, namun
Pemerintah Indonesia (KLH) sudah memberikan izin untuk land application dengan persyaratan-persyaratan yang ketat. Pabrik Kelapa Sawit PT. Smart Tbk adalah salah satu PKS yang sudah mendapatkan izin dan melaksanakan land application.

Sejauh ini telah dikenal dua sistem land application, yaitu long bed untuk lahan yang rata dan flat bed untuk lahan yang landai. Penggunaan land application ini harus disesuaikan dengan sifat tanah dan kondisi curah hujan di lokasi perkebunannya. Aplikasi lahan di PTPN IV Bah Jambi adalah sebagai berikut :

- $\quad$ Long Bed : Ukuran Bed = panjang $x$ lebar $\mathrm{x}$ dalam $=100 \mathrm{~m} \times 0,5 \mathrm{~m} \times 0,5$ $\mathrm{m}$.

- $\quad$ Flat Bed : Ukuran Bed = panjang $\mathrm{x}$ lebar $\mathrm{x}$ dalam $=2,5 \mathrm{~m} \times 1,5 \mathrm{~m} \times 0,3$ $\mathrm{m}$. Dalam sistem flat bed setiap bed dihubungkan dengan suatu parit kecil dengan dimensi (panjang $x$ lebar $x$ dalam) $=1,0 \mathrm{~m} \times 0,4 \mathrm{~m} \times 1,0 \mathrm{~m}$.

\section{SISTEM TEKNOLOGI PENGOLAHAN LIMBAH CAIR YANG DIUSULKAN}

Berdasarkan survey dan wawancara yang telah dilakukan langsung di beberapa Pabrik Kelapa Sawit yang ada di Indonesia, diperoleh gambaran bahwa masih banyak PKS yang belum melaksanakan pengolahan yang benar terhadap limbah cair yang dihasilkannya. Banyak PKS yang hanya menggunakan kolam-kolam galian dan menyebutkan bahwa kolam-kolam tersebut adalah kolam anaerobik dan yang lainnya adalah kolam aerobik. Namun kenyataannya di lapangan, kolam-kolam tersebut tidak dioperasikan dan dipelihara dengan benar. Akibatnya keberadaan kolamkolam tersebut menjadi hanya formalitas belaka. Karena itu, saat ini sudah harus dibutuhkan suatu sistem yang baku tentang pengolahan limbah cair dari suatu PKS.

Berdasarkan data tentang komposisi 
limbah cair PKS, diketahui bahwa beban BOD merupakan $80 \%$ lebih dari jumlah limbah yang dihasilkan. Dengan demikian, limbah cair PKS didominasi oleh limbah organik dan sistem pengolahannya pun akan didominasi oleh proses biologis. Hal itu tidak berarti bahwa proses fisika dan kimia tidak dipergunakan, tetapi diterapkan hanya pada proses awal dan akhir saja. Proses-proses dalam sistem pengolahan limbah cair PKS dapat dilihat pada Gambar 2. disirkulasi melalui tangki sirkulasi. Proses sirkulasi ini dapat digunakan pula sebagai optimalisasi proses anaerobik dan juga untuk pengendalian jumlah lumpur dalam tangki reaktor anaerobik. Proses selanjutnya adalah proses aerobik dengan penghembusan udara atau dengan sistem pengadukan di sekitar permukaan air limbah yang akan diolah. Setelah proses aerobik selanjutnya adalah pengendapan lumpur. Seperti juga pada proses anaerobik yang menggunakan sirkulasi lumpur aktif,

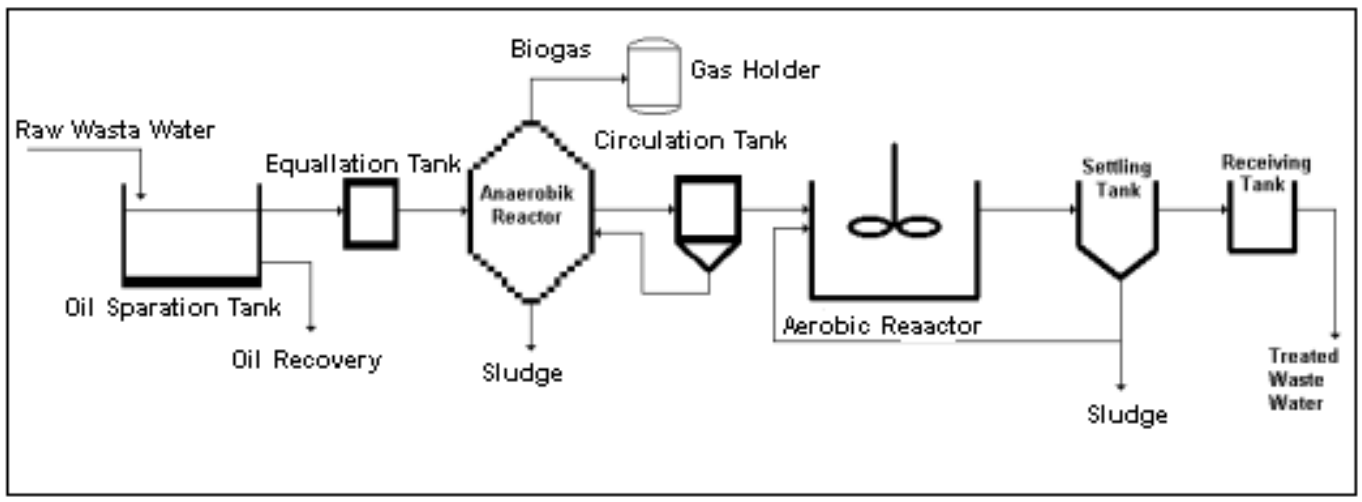

Gambar 2 : Diagram Alir Proses Pengolahan Limbah Cair Industri CPO

Proses pengolahan diawali dengan pengendapan awal yang diakomodasikan dalam unit Oil Separation Tank. Dalam tangki pengendap awal ini juga terjadi pemisahan minyak yang masih banyak terdapat dalam limbah cair yang dibuang, sehingga dengan pengambilan minyak dalam limbah cair ini jelas akan meningkatkan efisiensi proses produksi secara keseluruhan. Karena umumnya limbah cair kelapa sawit bersifat asam, maka proses selanjutnya adalah proses netralisasi. Setelah penetralan proses selanjutnya adalah proses utama yaitu proses anaerobik. Dalam tangki reaktor anaerobik ini dihasilkan gas bio yang akan ditampung dalam tangki Gas Holder dan selanjutnya gas bio (gas methan) tersebut untuk dimanfaatkan guna keperluan proses pemanasan dalam pabrik CPO. Lumpur aktif yang terdapat dalam proses anaerobik demikian pula dengan proses aerobik. Sebagian lumpur aktif yang mengendap pada bagian bawah tangki pengendap disirkulasi kembali ke dalam tangki reaktor aerobik. Sebagai proses akhir adalah pengeringan lumpur dalam unit pengeringan lumpur (drying bed) $)^{4)}$.

\section{KESIMPULAN DAN SARAN}

1). Dari PKS-PKS yang ada di PTP. Nusantara IV dan VIII, yaitu di Bah Jambi dan Kabupaten Lebak menunjukkan bahwa, maka sistem pengolahan limbah cair PKS dengan mengalirkan limbah cair tersebut ke beberapa kolam-kolam yang luas. Sebagai perbandingan , yaitu luas lahan perkebunan kelapa sawit pada paling sedikit $30.000 \mathrm{Ha}$ dan luas total yang 
dibutuhkan untuk pengolahan limbah cair sekitar5 Ha.

2). Berdasarkan penelitian diketahui bahwa pengolahan limbah cair PKS sistem anaerobik telah menunjukkan hasil yang baik, yaitu dengan kebutuhan luas lahan yang sangat sedikit (lebih kecil dari 1 $\mathrm{Ha})$ sebagai secara kualitas sudah memenuhi baku mutu lingkungan.

3). Aplikasi pemanfaatan limbah cair PKS untuk menyuburkan lahan kelapa sawit harus terus dimonitor, sehingga tidak melampaui kemampuan daya dukung lahan perkebunan itu sendiri. Apabila jumlah limbah cair yang dialirkan ke lahan perkebunan melampaui batas kemampuannya, maka yang terjadi adalah pencemaran air tanah.

4). Suatu alur proses pengolahan limbah cair PKS seperti yang ditampilkan pada Gambar 2, sebenarnya juga tidak jauh berbeda dengan sistem RANUT. Upaya peningkatan efisiensi proses pengolahan limbah cair PKS harus terus dilakukan, misalnya dengan menerapkan sistem thermophilic. Dengan cara thermophilic yang khusus diterapkan untuk unit reaktor anaerobik, kemampuan bakteri pengurai akan meningkat, sehingga proses pengolahannyapun akan lebih efisien lagi. Namun dalam aplikasi sistem ini tentu dibutuhkan disain teknis yang baik untuk mencegah panas hilang yang digunakan untuk menjaga temperatur proses yang berkisar antara $40-50^{\circ} \mathrm{C}$.

\section{DAFTAR PUSTAKA}

1. P. Nugro Rahardjo, "Identifikasi Masalah Teknis Instalasi Pengolahan Air Limbah Pabrik Minyak Kelapa Sawit PT. Kertajaya", Majalah Analisa Sistem, Kedeputian Analisa Sistem, BPPT, April, 2003.

2. Anonymous, "Pengolahan Limbah Pabrik Kelapa Sawit”, Pusat Penelitian Kelapa Sawit, Medan, 1994.

3. Anonymous, "Pengendalian dan Pengoperasian Limbah Pabrik Kelapa Sawit",1999, Pusat Penelitian Perkebunan (RISPA), Medan, 1992.

4. P. Nugro Rahardjo, 1997, "Teknologi Pengolahan Limbah Cair Industri Minyak Mentah Kelapa Sawit", Laporan Teknis, Jakarta, 1997 


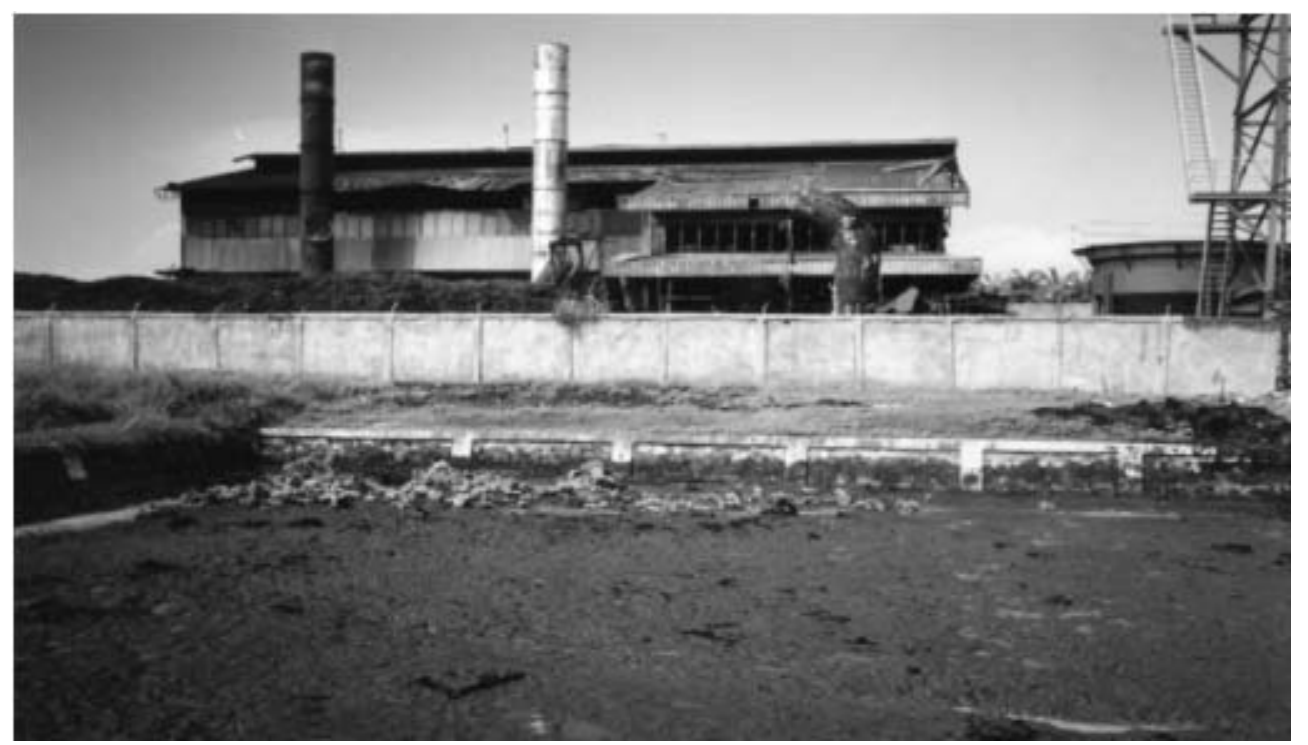

Gambar 3 : Unit kolam anaerobik yang sudah penuh dengan lumpur endapan (gambar latar belakang adalah pabrik kelapa sawit PT. Kertajaya).

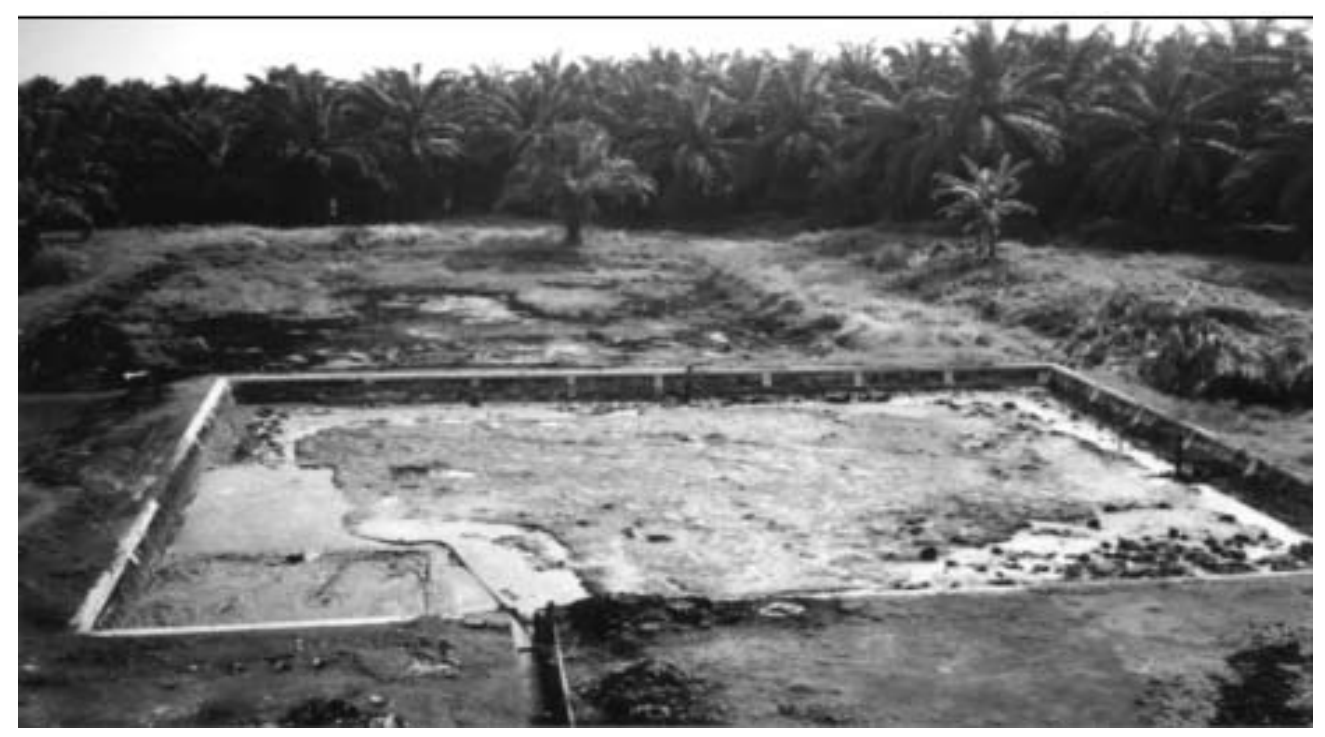

Gambar 4 : Unit kolam aerobik yang sudah penuh dengan lumpur endapa dan mulai terbentuknya channelling. 